African Crop Science Journal by African Crop Science Society is licensed under a Creative Commons Attribution 3.0 Uganda License. Based on a work at www.ajol.info/ and www.bioline.org.br/cs DOI: https://dx.doi.org/10.4314/acsj.v28i4.2

\title{
PHENOTYPIC DIVERSITY AND CHEMICAL PROPERTIES OF PAWPAW FRUIT QUALITY IN UGANDAN GERMPLASM
}

\author{
E. NUWAMANYA ${ }^{1,2}$, O. AMPURIRE ${ }^{1}$, Y.MUKASA ${ }^{3}$, A. KATUNGISA ${ }^{1,2}$, M. KANAABI ${ }^{2}$ \\ and E. SSERUNJOGI MUKIIBI ${ }^{2}$ \\ ${ }^{1}$ College of Agricultural and Environmental Sciences, Makerere University, P. O. Box, 7062, \\ Kampala, Uganda \\ ${ }^{2}$ National Crops Resources Research Institute, P. O. Box, 7084, Kampala, Uganda \\ ${ }^{3}$ National Agricultural Research Laboratories, P. O. Box 7065, Kampala, Uganda \\ Corresponding author: nuwamanyaephraim@gmail.com, enuwamanya@caes.mak.ac.ug
}

(Received 15 April 2020; accepted 16 November 2020)

\begin{abstract}
Pawpaw (Carica pawpaw L.) fruit production and utilisation have been on the increase in Uganda. However, challenges related to identification of phenotypes with inherent characteristics for improvement of fruit shelf life have limited identification of better varieties. The objective of this study was to evaluate the phenotypic diversity and shelf life determinants of Uganda's pawpaw accessions and their variations based on selected quality parameters. Nineteen accessions were collected as seeds from different markets of Uganda, germinated and planted in Namulonge-Wakiso district, central Uganda. The accessions were significantly $(\mathrm{P}<0.05)$ variable in terms of fruit weight parameters, with dry matter ranging from $14-19 \%$ and fruit weight of up to $3.9 \mathrm{~kg}$; while pulp weight was up to $3.2 \mathrm{~kg}$ per fruit. Pulp firmness parameters were also significantly variable $(\mathrm{P}<0.05)$ and highly correlated with shelf life of the fruit, which ranged from 7 - 13 days depending on the accession. Fruit pulp pH ranged from 4.4-5.6; while titratable acidity of the fruit ranged from $0.03-0.08 \%$. The accessions were clustered in four main clusters depending on the fruit firmness properties, fruit shelf life, fruit weight, $\mathrm{pH}$ and titratable acidity as definitive parameters. These accessions were distinguished based on morphological parameters, and henceforth defined for nutritional and economic uses. Accessions with high fruit firmness (>5 kg F) such as 16/20'16/16, 16/17 and 18/1; and external pulp thickness ( $>2 \mathrm{~cm}$ ) such as 16/ $16,16 / 17$ and 18/1 had improved fruit shelf life and are recommended for marketability and processing.
\end{abstract}

Key Words: Carica pawpaw, fruit firmness, morphology, nutrition

\section{RÉSUMÉ}

La production et l'utilisation de fruits de papaye (Carica pawpaw L.) ont augmenté en Ouganda. Cependant, les défis liés à l'identification des phénotypes ayant des caractéristiques inhérentes à l'amélioration de la durée de conservation des fruits ont limité l'identification des meilleures variétés. L'objectif de cette étude était d'évaluer la diversité phénotypique et les déterminants de la durée de 
conservation des accessions de papaye en Ouganda et leurs variations en fonction de certains paramètres de qualité. Dix-neuf accessions ont été collectées sous forme de semences sur différents marchés de l'Ouganda, germées et plantées dans le Namulonge, district de Wakiso, à l' Ouganda centrale. Les accessions étaient significativement variables $(P<0,05)$ en termes de paramètres de poids des fruits, avec une matière sèche allant de 14 à $19 \%$ et un poids des fruits allant jusqu'à $3,9 \mathrm{~kg}$; tandis que le poids de la pulpe atteignait $3,2 \mathrm{~kg}$ par fruit. Les paramètres de fermeté de la pulpe étaient également significativement variables $(\mathrm{P}<0,05)$ et fortement corrélés à la durée de conservation du fruit, qui allait de 7 à 13 jours selon l'accession. Le pH de la pulpe de fruit variait de 4,4 à 5,6; tandis que l'acidité titrable du fruit variait de 0,03 à $0,08 \%$. Les accessions ont été regroupées en quatre groupes principaux selon les propriétés de fermeté du fruit, la durée de conservation du fruit, le poids du fruit, le pH et l'acidité titrable comme paramètres définitifs. Ces accessions ont été distinguées sur la base de paramètres morphologiques, et définies à la base des usages nutritionnels et économiques. Les accessions à forte fermeté du fruit ( $>5 \mathrm{~kg} \mathrm{~F}$ ) telles que 16/20 '16/16, $16 / 17$ et 18/1; et une épaisseur de pulpe externe ( $>2 \mathrm{~cm}$ ) telle que 16/16,16/17 et 18/1 avaient une durée de conservation améliorée des fruits, et elles sont recommandées pour la commercialisation et la transformation.

Mots Clés: Carica papaye, fermeté du fruit, morphologie, nutrition

\section{INTRODUCTION}

Pawpaw (Carica pawpaw L.) is a popular fruit in Uganda, praised for its abundant supply of vitamins, dietary fiber and minerals. It is mainly eaten fresh, and thus provides for the much needed external enzymes such as papain and chymopapain that improve digestibility of food, especially proteins (Oothman, 2009). The fruit also has significant levels of antiinflammatory and antioxidant properties, with health benefits for consumers (Adai, et al., 2013). It is because of such advantages that the fruit has found several uses and is one of the most traded and consumed fruits in Uganda (Weekly Market Insight, 2018)

In addition, there is a lucrative and fast growing local and export market for pawpaw. This is linked to increased production that is linked to pawpaw's low labour requirements, short growth cycle and high returns on investment (Weekly Market Insight, 2018). However, the returns on investment depend on the volume of harvest at a particular time and the ability to maintain fruit quality until consumption (Nyapendi et al., 2003; Weekly Market Insight, 2018). Thus, pawpaw presents high market opportunities compared to most other fruits grown in Uganda (Nyapendi et al., 2003) and can be promoted as an income generating crop among resource poor farmers as long as its fruit quality properties are improved.

The Weekly Market Insight report (2018), identified four main "varieties" of pawpaw grown in Uganda, as the Solo "variety", Mountain "variety", Sunrise "variety" and the Red Royale "variety". The fruit shape and size vary between these varieties, which influences their utilisation for different purposes. Importantly, one of the recommendations in Weekly Market Insight (2018) is for farmers to grow what they can sell, given the low shelf life of the fruit, with deterioration happening even before harvest. The low shelf life also affects the fruit quality and fruit appeal, which adversely affect its market value.

From the above observations, the importance of understanding the role of heritable characteristics in the determination of fruit quality is evident. It is imperative that farmers are guided in the choice of the "variety" to be grown in order to meet the consumer preferences (Olabode et al., 2015). This is because fruit quality properties are important in the selection of fruits that would satisfy consumer demand. They are also important indicators of post-harvest management demands for a particular "variety"; and can be based on to identify better 
varieties for specific markets. For example, in a study by Nwofia and Oku (2012), it was observed that variation in dry matter content, as a function of moisture content of the fruit, are important fruit parameters that will determine fruit shelf-life. In a related study by Oothman (2009), quality indicators such as chemical compositional changes, increase in moisture, and decrease in level of micronutrients during storage resulted into decreased shelf life. Changes in the quantity of the quality indicators, therefore, influence the choice of the fruit by consumers, and hence should influence the production and usability trends of specific varieties.

Among the many important fruit quality parameters is fruit firmness, which describes the internal and external hardness of the fruit and hence fruit acceptability (Galli et al., 2007). Fruit firmness has been used to infer loss in quality where minimal loss in firmness is directly linked to respiratory and climacteric changes in fruits (Archibold and Pomper, 2003). Indeed, loss of firmness is also associated with changes in activities of fruit based enzymes (Koslanund et al., 2005). This implies that such a trait is heritable and can be selected for, in different varieties to provide for fruits with better firmness characteristics. It should be noted that such traits inherent in the fruit are affected by storage practices (Galli et al., 2009), and hence should be leveraged to provide for the most appropriate fruit storage strategy. In addition, fruit chemical parameters such as $\mathrm{pH}$ and titratable acidity also describe the fruit's ability to maintain its quality under different storage conditions (Awe et al., 2013).

Given the fact that Uganda's pawpaw germplasm is made up of a range of pawpaw accessions, grown in different areas, the need to characterise these accessions is justified. Characterisation of the accessions will identify inherent fruit characteristics that influence fruit quality. The characterisation will also provide credible information to stakeholders on inherent fruit quality characteristics and their influence on fruit shelf life. This study was, therefore, conducted to evaluate the phenotypic diversity and shelf life determinants of Uganda's pawpaw accessions and their variations based on selected quality parameters.

\section{MATERIALS AND METHODS}

Pawpaw fruits were obtained from an established pawpaw germplasm at the National Crops Resources Research Institute (NaCRRI) in Uganda, containing 19 accessions. The 19 accessions were obtained from locally available pawpaw varieties and landraces, collected from all over Uganda between 2016 and 2018 as seeds. These collections were coded based on their differences in fruit morphological characteristics; and established in an open field at NaCRRI (Altitude: 1,160 $\mathrm{m}$, Latitude: 0.5250; Longitude:32.6150) in Namulonge, central Uganda.

For this study, each accession was evaluated based on fruits collected on availability basis; and data aggregated over a period of six months. Fruits were harvested from each accession in plots of $6 \mathrm{~m}$ by $6 \mathrm{~m}$, each containing 9 plants. Fruits were harvested when the colour change from green to yellow or light green signifying the beginning of ripening was observed on a particular fruit (Galli et al., 2007).

Fruits were then hand picked randomly as they matured, i.e. at colour break stage, with three replications (plant stands) for each accession. The fruits were placed gently in a crate in single layers, transported to the storage room, labelled and placed on wooden surfaces at $18^{\circ} \mathrm{C}$ ready for analysis. Quality related parameters determined included fruit weight properties, fruit firmness characteristics and critical fruit chemical properties of $\mathrm{pH}$ and titratable acidity.

\section{Fruit weight characteristics}

Fruit dry matter content. Fruit dry matter content was determined gravimetrically at 70 ${ }^{\circ} \mathrm{C}$ for 24 hours. The pawpaw fruit was cut longitudinally, followed by removal of seeds and seminal teguments. This was followed by 
peeling to remove the skin using a knife. The peeled sample was chopped and $100 \mathrm{~g}$ (weight A) of flesh from opposite portions of the fruit was placed on a new sterile aluminum plate. Each sample was taken in duplicates and oven dried at $70{ }^{\circ} \mathrm{C}$ for 24 hours for dry weight determination. Dry weight was then calculated as follows:

Dry matter $=\frac{\mathrm{A}-\mathrm{B}}{100} \times 100 \% \ldots \ldots .$. Equation 1

Fruit and pulp weights. Fruit weight for the whole fruits was taken for each sample using an electronic weighing scale (S/SI-4002, Denver instruments), immediately after harvesting. Pulp weight was taken for each peeled fruit also immediately after harvesting.

Fruit firmness. Pulp thickness was taken using a $15 \mathrm{~cm}$ mathematical set ruler (Helix Oxford). Longitudinal sections of the fruit samples were cut per fruit. Fruit pulp thickness was measured on the broadest part of the fruit, approximately half way the fruit length (Branan and Wang, 2017).

Presence of hard lump pulps was assessed by physical observation of the peeled fruit, accompanied by hand pressing to feel distinguished hardness of some pulp parts. Presence of hard lump pulps was scored according to De Oliveira and Vitória (2011), based on the intensity of hard lump pulps within the fruit after ripening.

Fruit firmness for different fruit samples was measured using a fruit firmness meter (penetrometer) according to Chutichudet and Chutichudet (2014), with minor modifications. The penetrometer was held by hand and vertically pressed into the fruit flesh on a randomly selected site, on the intact belly of the fruit, without exceeding the measurement mark provided on the instrument into the fruit. Then, the readings were taken directly from the penetrometer. This was done for 3 points on the fruit and the average obtained. The same procedure was followed for the internal fruit firmness.
Fruit shelf life and pulp colour. Pawpaw fruits shelf life was determined at physiological maturity for the different accessions kept on a counter in the open at room temperature. The fruits were monitored at a day's interval from the beginning of ripening, until visible watery islands were observed on the fruit surface (time when the fruit is deemed unfit for consumption) and the time taken was recorded.

Pulp colour shed names were determined using the Royal Horticultural Society Colour Chart (RHS, 2015), by comparison under natural light, and the corresponding colour recorded.

Fruit chemical properties. For $\mathrm{pH}$ and total titratable acidity, $20 \mathrm{~g}$ of the fruit pulp was taken per sample and crushed for 3 minutes using a laboratory blender, to extract the juice. The contents were filtered using a cheese cloth and then diluted up to $100 \mathrm{ml}$ using deionised water. Using freshly prepared samples, $\mathrm{pH}$ was measured using a $\mathrm{pH}$ meter. Titratable acidity was measured using the same extracts by titrating the juice using $0.05 \mathrm{M} \mathrm{NaOH}$ solution to raise the $\mathrm{pH}$ to 8.3 . The average volume of $\mathrm{NaOH}$ used was recorded. The results were expressed as a percentage of citric acid which is the main organic acid in pawpaw fruits, viz.:

Titration acidity $(\%)=$

[mls $\mathrm{NaOH}$ used] x [Molarity of $\mathrm{NaOH}$ x [milliequivalent factor]x[100] 20 Equation 2

Data analysis. All data collected were recorded in Excel data sheets. Quantitative data were subjected to analysis of variance for Completely Randomised Design (CRD), using and XLSTAT student version 2019.1. To assess differences between the accessions, Fisher's Protected Least Significant Difference (LSD) was used at $95 \%$ confidence level.

Data on fruit colour were summarised using cross tabulations. Grouping of varieties was done using hierarchical cluster analysis, based on the UPGMA Principal Component 
Analysis to determine the most relevant definitive parameters for fruit quality.

Correlation analysis was undertaken to determine the relationships between fruit quality parameters and, therefore, select definitive parameters for routine use in morpho-physio analyses.

\section{RESULTS AND DISCUSSION}

Fruit weight parameters. Fruit weight parameters observed in the study are described in Table 1. Dry matter content was significantly different $(\mathrm{P}<0.05)$ for all the accessions; and ranged from $14.4 \%$ in accession $18 / 25$ to $19.2 \%$ in accession 18 / 16.The results observed were within the known ranges for dry matter for pawpaw fruits (Oothman, 2009). Dry matter content is a function of total dry mass of the fruit, including minor and major metabolites in the fruit pulp. Apart from variations within the fruit, dry matter content may also vary with fruit harvesting time and environmental factors affecting the fruit. Thus the observed accessions specific variations could also have been attributed to environment based differences since specific harvesting times were adhered to (Iroka et al., 2016). The differences observed also show that accessions with different dry matter contents can be earmarked for different applications.

Fruit weight was also significantly different $(\mathrm{P}<0.05)$ and ranged from $1158 \mathrm{~g}$ of fresh weight in accession $18 / 1$, to $3876 \mathrm{~g}$ in accession 16/15 (Table 1). Pawpaw fruit weight influences consumer preference during marketing. However, this depends on the

TABLE 1. Pawpaw fruit weight parameters determined from the study accessions in Uganda

\begin{tabular}{llcccc}
\hline $\begin{array}{l}\text { Accession } \\
\text { number }\end{array}$ & $\begin{array}{c}\text { Accession } \\
\text { code }\end{array}$ & $\begin{array}{c}\text { Dry matter } \\
(\%)\end{array}$ & $\begin{array}{c}\text { Fruit } \\
\text { weight }\end{array}$ & $\begin{array}{c}\text { Pulp } \\
\text { weight }\end{array}$ & $\begin{array}{c}\text { Skin } \\
\text { weight }(\mathrm{g})\end{array}$ \\
\hline 1 & $16 / 1$ & 17.80 & 1381.2 & 1085.2 & 295.7 \\
2 & $16 / 10$ & 15.87 & 1348.5 & 978.4 & 370.6 \\
3 & $16 / 15$ & 17.87 & 3876.0 & 3199.0 & 677.2 \\
4 & $16 / 16$ & 16.90 & 2911.7 & 2195.3 & 716.0 \\
5 & $16 / 17 \mathrm{R}+\mathrm{L}(\mathrm{R})$ & 18.37 & 1523.3 & 1154.3 & 369.4 \\
6 & $16 / 18 \mathrm{R}+\mathrm{L}(\mathrm{L})$ & 17.60 & 1251.4 & 980.8 & 270.1 \\
7 & $16 / 19$ & 17.00 & 1341.7 & 1068.2 & 273.5 \\
8 & $16 / 20$ & 17.67 & 2471.7 & 1906.7 & 565.2 \\
9 & $16 / 3$ & 18.13 & 1640.5 & 1306.3 & 334.3 \\
10 & $16 / 4$ & 18.50 & 1478.1 & 1153.4 & 325.0 \\
11 & $16 / 5$ & 16.13 & 3271.9 & 2576.8 & 695.0 \\
12 & $16 / 6$ & 16.03 & 1554.4 & 1234.2 & 320.0 \\
13 & $18 / 1$ & 18.60 & 1157.7 & 1072.2 & 86.2 \\
14 & $18 / 10$ & 15.77 & 1776.5 & 1350.5 & 426.4 \\
15 & $18 / 16$ & 19.20 & 3068.8 & 2394.9 & 674.4 \\
16 & $18 / 20$ & 17.43 & 2226.2 & 1774.0 & 451.8 \\
17 & $18 / 25$ & 14.40 & 1277.8 & 1015.2 & 263.1 \\
18 & $18 / 4$ & 18.93 & 1421.0 & 1091.3 & 330.2 \\
19 & $18 / 5$ & 17 & 2237.6 & 1486.8 & 750.8 \\
& & & & ns & \\
& P value & $<0.001$ & $<0.001$ & $<0.001$ & $<0.001$ \\
& LSD & 0.6449 & 451.1 & 394.7 & 99.7 \\
& Cv (\%) & 2.2 & 13.9 & 15.6 & 22.3 \\
\hline
\end{tabular}


market, with the local market in Uganda preferring fruits with higher weight values (big fruits) compared to small fruits (Weekly Market insight, 2018). It has been noted by Crabtree et al. (2010) that pawpaw with higher fruit and pulp weights tend to have a bigger peduncle that makes harvesting easy and reduces incidences of damage, that ultimately lead to increased post-harvest deterioration. Therefore, apart from fruits with bigger weights being demanded by markets, such fruits or accessions with high fruit weight may be selected due to their better handling properties during fruit marketing and storage. Pulp weight, which is also related to fruit weight, ranged from $978 \mathrm{~g}$ in accession 16/ 10 , up to $3199 \mathrm{~g}$ in accession 16/15; and was also significantly different $(\mathrm{P}<0.05)$ among the studied accessions. Pulp weight represents the marketable and process-able portion of the fruit. Fruits with high pulp weight are generally preferred for processing (Othman, 2009). Thus, fruits with high pulp weights can be promoted among farmers as long as their shelf life is sufficient for marketing and processing.

Variable values for skin weight were also derived as the difference between total weight of fruits and pulp weight. Skin weight, ranged from $86 \mathrm{~g}$ in accession 18/1 with the thinnest skin, to $751 \mathrm{~g}$ in accession $18 / 5$ with the thickest skin. Skin weight was positively correlated with fruit skin thickness and has been found to influence fruit shelf life in apples (Homutová and Bla•ek, 2006). Therefore, fruits with more skin weight could be selected for improved shelf life in pawpaw as was observed in this study (Table 1).

Fruit firmness characteristics. Fruit firmness characteristics were significantly different for all the parameters tested, namely pulp thickness, presence of hard lumps in the pulp, external firmness of the pulp as measured from the skin, and internal firmness of the pulp (Table 2). According to Homutová and Bla•ek (2006), fruit firmness is critical in the postharvest handling of fruits, where firm fruits have better fruit quality than their softer counterparts. Thus, fruits with more firmness after harvest can be selected for improved fruit quality.

In this study, the firmness of the fruit varied significantly in relation to measurements on the outside (external firmness) or the inside (internal firmness) of the fruit (Table 2). The external part of the fruit had firmness readings ranging from $2.23 \mathrm{~kg} \mathrm{~F}$ in accession $16 / 5$ to $9.73 \mathrm{~kg} \mathrm{~F}$ in accession 16/16, with significant $(\mathrm{P}<0.05)$ differences observed in all the accessions. Internal firmness also ranged from 0.197 to $1.35 \mathrm{~kg} \mathrm{~F}$. Due to presence of the skin, the external firmness was higher than the internal firmness which represents the firmness of the pulp. Accessions with high external firmness have been observed to have increased shelf life (Marpudi et al., 2011), and therefore, can be selected for use in applications requiring higher shelf life. They can also be used in improvement of pawpaw germplasm, in terms of shelf life. The ratio of external firmness to internal firmness was calculated (Table 2) to provide a reliable indicator of the extent of fruit firmness as a whole (López-Gómez et al., 2009). The most firm accession was $16 / 17$ with an external and internal firmness ratio of $3.14 \mathrm{~kg} \mathrm{~cm}^{-2}$; while the least firm accession was $16 / 5$ with a ratio of $0.726 \mathrm{k} \mathrm{cm}^{-2}$ (Table 2). However, based on internal thickness, the accession with the most firm pulp was $16 / 16$ with a ratio of 0.673 $\mathrm{kg} \mathrm{cm}^{-2}$; while the accession with the least firm flesh was $16 / 4$ with the ratio of $0.087 \mathrm{~kg}$ $\mathrm{cm}^{-2}$. The higher the ratio, the "firmer" the pulp, and hence selection for fruit with an intact pulp can be based on this ratio.

In this study, therefore, fruits with a higher ratio are recommended for use, especially where fruits need to be taken to markets away from production areas. Such fruits can withstand the rigours of transportation and still maintain appreciable fruit quality (BosquezMolina et al., 2011). In addition, Fruit firmness has various implications on the quality and physiological state of the fruit. It is an indicator of quality, where losses in firmness may lead to skin pitting in fruits; hence loss in size and 
TABLE 2. Pawpaw fruit firmness characteristics and pulp properties observed in accessions in Uganda

\begin{tabular}{|c|c|c|c|c|c|c|c|}
\hline $\begin{array}{l}\text { Accession } \\
\text { number }\end{array}$ & $\begin{array}{l}\text { Accession } \\
\text { code }\end{array}$ & $\begin{array}{l}\text { Pulp } \\
\text { thickness } \\
(\mathrm{cm})\end{array}$ & $\begin{array}{l}\text { Hard } \\
\text { lump } \\
\text { pulp }\end{array}$ & $\begin{array}{l}\text { External } \\
\text { firmness } \\
(\mathrm{Kgf})\end{array}$ & $\begin{array}{l}\text { Internal } \\
\text { firmness } \\
(\mathrm{Kgf})\end{array}$ & $\begin{array}{l}\text { Ext/Pulp } \\
\text { thickness } \\
\left(\mathrm{kg} \mathrm{cm}^{-2}\right)\end{array}$ & $\begin{array}{l}\text { Int/Pulp } \\
\text { thickness } \\
\left(\mathrm{kg} \mathrm{cm}^{-2}\right)\end{array}$ \\
\hline 1 & $16 / 1$ & 3 & 2 & 3.51 & 0.29 & 1.17 & 0.15 \\
\hline 2 & $16 / 10$ & 3.1 & 1 & 3.49 & 0.33 & 1.123 & 0.33 \\
\hline 3 & $16 / 15$ & 3.57 & 1 & 3.49 & 0.39 & 0.98 & 0.39 \\
\hline 4 & $16 / 16$ & 3.77 & 2 & 9.73 & 1.33 & 2.58 & 0.67 \\
\hline 5 & $16 / 17 \mathrm{R}+\mathrm{L}(\mathrm{R})$ & 1.93 & 2.33 & 6.06 & 0.84 & 3.15 & 0.36 \\
\hline 6 & $16 / 18 \mathrm{R}+\mathrm{L}(\mathrm{L})$ & 2.83 & 2.33 & 4.5 & 0.58 & 1.59 & 0.25 \\
\hline 7 & $16 / 19$ & 3.07 & 2 & 3.24 & 0.36 & 1.06 & 0.18 \\
\hline 8 & $16 / 20$ & 3.57 & 3.67 & 5.26 & 0.73 & 1.47 & 0.2 \\
\hline 9 & $16 / 3$ & 2.63 & 1.67 & 3.97 & 0.55 & 1.51 & 0.33 \\
\hline 10 & $16 / 4$ & 3.57 & 3.67 & 3.91 & 0.32 & 1.1 & 0.09 \\
\hline 11 & $16 / 5$ & 3.07 & 1 & 2.23 & 0.22 & 0.73 & 0.22 \\
\hline 12 & $16 / 6$ & 3.3 & 2.33 & 2.51 & 0.2 & 0.74 & 0.08 \\
\hline 13 & $18 / 1$ & 2.47 & 1.33 & 6.02 & 0.95 & 2.44 & 0.71 \\
\hline 14 & $18 / 10$ & 3.57 & 3.67 & 3.17 & 0.34 & 0.89 & 0.09 \\
\hline 15 & $18 / 16$ & 3.93 & 1.33 & 7.35 & 0.86 & 1.87 & 0.65 \\
\hline 16 & $18 / 20$ & 2.9 & 2.33 & 4.94 & 0.63 & 1.71 & 0.27 \\
\hline 17 & $18 / 25$ & 3.7 & 1.33 & 4.16 & 0.52 & 1.12 & 0.39 \\
\hline 18 & $18 / 4$ & 3.7 & 2 & 4.13 & 1.06 & 1.12 & 0.53 \\
\hline \multirow[t]{4}{*}{19} & $18 / 5$ & 3.23 & 2.33 & 3.53 & 0.34 & 1.2 & 0.15 \\
\hline & $P$ value & $<0.001$ & $<0.001$ & $<0.001$ & $<0.001$ & & \\
\hline & LSD & 0.2934 & 0.8526 & 0.5189 & 0.1573 & & \\
\hline & $\mathrm{Cv}(\%)$ & 5.5 & 24.9 & 7 & 16.7 & & \\
\hline
\end{tabular}

weight (Marpudi et al., 2011). This results into shorter shelf life and, hence low acceptability, which further depreciates the usability and hence the market value of the fruits. Much as changes during ripening may lead to loss in fruit firmness (López-Gómez et al., 2009), these changes should be minimal in order to ensure better fruit quality and shelf life. Where such changes are high, the loss in firmness also predisposes the fruit to attack by bacterial and fungal pathogens (Osman et al., 2011), which adversely affects fruit quality, leading to other changes that reduces the market value of the fruit. Therefore, varieties with high inherent firmness properties would be preferred for processing activities (BosquezMolina et al., 2011).
Pulp thickness for all the accessions studied ranged from $1.9 \mathrm{~cm}$ in accession $16 / 17$ to 3.9 $\mathrm{cm}$ in accession 18/16 (Table 2). Accordingly, accession $18 / 16$ with a bigger pulp presented bigger and juicer fruits compared to others. Farmers and consumers are more likely to select fruits with a bigger pulp given the high market value they present regardless of the shelf life of such fruits (Brannan and Wang, 2017).

Hard lump scores ranged from score 1 to 3.7 for varieties $16 / 4$ and $18 / 10$, respectively (Table 2). Presence of hard lumps in the pulp show loss in the post-harvest quality of pawpaw fruits (Paull et al., 1997). These lumps increase the rate of deterioration in the fruit and have significant effects on fruit shelf 
life (Paull et al., 1997; Shiga et al., 2009). Since possession of hard lump pulps is a response to stress in some pawpaw varieties (Paull et al., 1997), improved agronomy targeting offsetting stress can reduce the incidence of hard lump pulps and reverse the effects of such hard lumps on fruit quality and shelf life. Importantly, selections for accessions with low incidence of hard lumps should inform the farmers' choice of a variety to be used.

Fruit chemical properties. Total titratable acidity, $\mathrm{pH}$ and pigmentation of the pawpaw fruit were significantly $(\mathrm{P}<0.05)$ different among the accessions used in this study (Table 3 ). In particular, total titratable acidity ranged from $0.03 \%$ in accession $16 / 18$, to $0.079 \%$ in accession 18/4. Titratable acidity is the measure of the hydrogen ion concentration of fruit juices. It also measures all the substances of an acidic nature in the fruit juice, including free hydrogen ions, organic acids, and acid salts. These components varied significantly within the test accessions.

Given the role of hydrogen ions in modulation of water activity, the level of titratable acidity is indicative of the preservation of fruit quality and prevention of fruit degradation arising from microorganism attack (Bosquez-Molina et al., 2010). Thus, fruits from accessions with higher titratable acidity such as $18 / 4$ are more likely to present a higher shelf life compared to those with low titratable acidity (Marpudi et al., 2011). On the other hand, $\mathrm{pH}$ ranged from 4.43 in accession 18/4 to 5.57 in accession 18/20. The $\mathrm{pH}$ of pawpaw juice represents the measure of the both the acidic and alkalinic components of the fruit, and is related to titratable acidity. In this study,

TABLE 3. Selected pawpaw fruit chemical properties and fruit colour for Uganda's pawpaw germplasm

\begin{tabular}{|c|c|c|c|c|}
\hline Accesion number & Germplasm & Titratable acidity (\%) & $\mathrm{pH}$ & Fruit colour \\
\hline 1 & $16 / 1$ & 0.060 & 4.80 & Yellow \\
\hline 2 & $16 / 10$ & 0.047 & 5.53 & Orange \\
\hline 3 & $16 / 15$ & 0.050 & 4.83 & Orange \\
\hline 4 & $16 / 16$ & 0.045 & 4.93 & Yellowish-orange \\
\hline 5 & $16 / 17 \mathrm{R}+\mathrm{L}(\mathrm{R})$ & 0.043 & 4.60 & Orange-red \\
\hline 6 & $16 / 18 \mathrm{R}+\mathrm{L}(\mathrm{L})$ & 0.030 & 4.83 & Yellow \\
\hline 7 & $16 / 19$ & 0.049 & 4.83 & Yellow \\
\hline 8 & $16 / 20$ & 0.047 & 5.80 & Yellowish-orange \\
\hline 9 & $16 / 3$ & 0.044 & 4.80 & Orange \\
\hline 10 & $16 / 4$ & 0.052 & 4.57 & Yellow \\
\hline 11 & $16 / 5$ & 0.041 & 4.63 & Orange \\
\hline 12 & $16 / 6$ & 0.044 & 4.70 & Orange \\
\hline 13 & $18 / 1$ & 0.066 & 4.60 & Yellow \\
\hline 14 & $18 / 10$ & 0.045 & 5.63 & Yellowish-orange \\
\hline 15 & $18 / 16$ & 0.040 & 4.97 & Yellowish-orange \\
\hline 16 & $18 / 20$ & 0.044 & 5.77 & Yellowish-orange \\
\hline 17 & $18 / 25$ & 0.040 & 4.67 & Orange-red \\
\hline 18 & $18 / 4$ & 0.079 & 4.43 & Orange \\
\hline \multirow[t]{4}{*}{19} & $18 / 5$ & 0.063 & 4.70 & Yellowish-orange \\
\hline & $P$ value & $<0.001$ & $<0.001$ & \\
\hline & LSD & 0.0058 & 0.110 & \\
\hline & $\mathrm{CV}(\%)$ & 7.1 & 1.4 & \\
\hline
\end{tabular}


accessions with high titratable acidity had lower $\mathrm{pH}$ values, confirming the contribution of titratable acidity in the reduction of overall $\mathrm{pH}$ of the fruit juice (Proulox et al., 2005). Differences in $\mathrm{pH}$ and total titratable acidity have implications on selection of varieties for processing of products, such as pawpaw juice; and use of pawpaw as additives during processing of fruit based products. A near neutral $\mathrm{pH}$ is preferred in most fruit juices and additives, including pawpaw (De Oliviera and Vitoria, 2011). Thus, the variability observed can be used for selection of best performing varieties for such purposes.

Pulp pigmentation or internal fruit colour in pawpaw varies among pawpaw fruits and is a determinant in fruit acceptability among consumers (Schweiggert et al., 2001; Crisoto et al., 2003). Fruit colour represents pigmentation of the pulp and is influenced by specific fruit pigments (Schweiggert et al., 2011). In this study, internal fruit colour varied from yellow to orange, with intermediate colours of yellowish orange observed in most genotypes at full ripening (Table 3). Colour differences were specific among accessions, much as they were influenced by the ripening time and the position of the fruit on the plant at harvest. However, the orange shade of the fruits was the most commonly observed colour among accessions.

The observed colours are an indication of the different brown to yellow pigments accumulated in pawpaw pulp during development, including carotenoids and lycopene pigment families (Schweiggert et al., 2011). These pigments are important nutritional components of the fruit and are indicative in solving various nutrition disorders, as observed by Crisosto et al. (2003). Indeed the colour of the pulp also influences consumer acceptance in most fruits including pawpaw. Therefore, the observed variability in pawpaw fruit colour is important in selecting for the most acceptable fruit types and promoting their production for the specified consumer groups. Studies into pawpaw fruit acceptability and sensorial analyses are needed to establish the most acceptable genotypes.

Determinants of pawpaw fruit shelf life. In pawpaw fruits, fruit shelf life is a critical quality parameter. From the principal component analysis (Table 4), fruit shelf life explained up to $71.4 \%$ of the observed variability in fruits. This showed that fruit shelf life should be considered in the identification of pawpaw fruits that are acceptable to consumers. Given the importance of shelf life, some of its determinants were determined from the correlation analysis (Table 5). The positive relationships between shelf life and fruit firmness $(r>0.7)$ showed that firmness characteristics (both internal and external) are largely the main determinants of shelf life. In addition, positive relationships between shelf life and dry matter content $(r>0.4)$ were indicative of the role of increased dry matter content as a determinant for better shelf life in fruits. Other determinants included pulp thickness and the $\mathrm{pH}$ where a thicker pulp was associated with improved shelf life while higher $\mathrm{pH}$ resulted into reduced fruit shelf life. Such determinants (such as dry matter content) can be evaluated even before the fruit is marketed and are important in selection of pawpaw accessions with improved shelf life.

Fruit shelf life. Fruit shelf life for the accessions used in this study ranged from 7 days to 13 days (Fig. 1). The lowest storage period of 7.67 days was observed in pawpaw fruits from accessions 16/6 and 16/5. These accessions had a lower shelf life and were thus more prone to faster fruit deterioration. On the other hand, accessions such as 18/16 showed a longer period before deterioration of 13 days showing that they had a higher shelf life. Thus, significant $(\mathrm{P}<0.05)$ differences were observed in fruit shelf life. Such differences in shelf life are inherent for accessions tested and are possibly related to morphological and physiological components of the fruit (Archbod and Pomper, 2003). 
TABLE 4. Squared cosines and eigen values of the first five principal components showing the relative importance of the 10 fruit quality parameters in determining variability within the 19 pawpaw germplasms

\begin{tabular}{lccccc}
\hline Fruit quality parameter & \multicolumn{5}{c}{ Principal components } \\
\cline { 2 - 6 } & PC1 & PC2 & PC3 & PC4 & PC5 \\
\hline External firmness & $\mathbf{0 . 8 2 7}$ & 0.001 & 0.076 & 0.046 & 0.001 \\
Internal firmness & $\mathbf{0 . 7 9 8}$ & 0.043 & 0.014 & 0.003 & 0.004 \\
Shelf life & $\mathbf{0 . 7 1 4}$ & 0.074 & 0.026 & 0.016 & 0.046 \\
Dry matter (\%) & $\mathbf{0 . 3 5 6}$ & 0.090 & 0.059 & 0.086 & 0.299 \\
pH & 0.013 & 0.146 & $\mathbf{0 . 5 2 6}$ & 0.002 & 0.059 \\
Titratable acidity & 0.019 & 0.185 & 0.175 & $\mathbf{0 . 4 4 8}$ & 0.005 \\
Pulp thickness & 0.037 & 0.252 & 0.028 & 0.267 & $\mathbf{0 . 3 6 3}$ \\
Fruit weight & 0.118 & $\mathbf{0 . 7 8 0}$ & 0.047 & 0.008 & 0.029 \\
Pulp weight & 0.123 & $\mathbf{0 . 7 6 1}$ & 0.063 & 0.004 & 0.035 \\
Hard lump pulp & 0.014 & 0.033 & $\mathbf{0 . 4 8 2}$ & 0.262 & 0.057 \\
Eigen value & 3.019 & 2.365 & 1.497 & 1.144 & 0.897 \\
Variability (\%) & 30.194 & 23.653 & 14.967 & 11.439 & 8.974 \\
Cumulative \% & 30.194 & 53.847 & 68.814 & 80.254 & 89.228 \\
\hline
\end{tabular}

Values in bold correspond for each parameter to the factor for which the squared cosine is the largest; PC represents principal components

Shelf life is an important fruit property as it determines the usability of the fruit after harvest (Shiga et al., 2009). Variability in fruit shelf life, therefore, has implications in the marketability of these fruits, in that fruits with short shelf life need to be marketed faster to avoid deterioration. Where easy marketing is not possible, the fruits can be processed into secondary products (Archbold and Pomper 2003). However, from the Ugandan perspective where processing technology is still lacking, selection of fruits from accessions with higher shelf life is the most viable option. In addition, since the export market is also targeted, most of the fruits showed that there is need to provide for shelf life enhancement procedure in case they have to be transported. Thus, deliberate efforts in improving pawpaw fruit shelf life are required in order to realise the full potential of the fruit.

Algometric hierarchical cluster analysis. The Euclidean dissimilarity coefficient based on UPGMA method, grouped the germplasm into four clusters (Fig. 2). Cluster 3 was the largest with 12 accessions and four outliers, namely 18/1, 16/19, 16/10 and 16/6. Clusters 1 and 2 had the same number of accessions, and were the second largest with 3 accessions each. Cluster 4 consisted of only one accession, i.e. 16/15. The dissimilarity distance between clusters was high for cluster four compared to the other three clusters (Table 4).

The observations from cluster analysis clearly showed that in Uganda, four main accessions of pawpaw are grown; which confirms earlier observations in the Weekly Markets Insight Report (2018) that identified four main morpho-types based on fruit characteristics. The grouping of pawpaw fruits as observed in this study is important for the identification of pawpaw fruit germplasm with the required genetics for improvement of fruit quality. As discussed by Casalas et al. (2012), the genetic basis for long 
shelf life as an important attribute in fruit quality, largely depends on the understanding the source of long shelf life related genes. In the present study, crosses between different clusters of pawpaw will be pertinent in generating pawpaw varieties with variable fruit characteristics and hence enabling selection for improved fruit quality.

Principle component analysis. The variations observed in the study as a result of PC analysis, were mainly explained by the first five components, which contributed $89.23 \%$ of the total variability observed, with Eigen values greater than 0.8 (Table 4). From the screen plot, all the ten parameters (represented by the five factors of the PCs) played a role in explaining variability (Fig. 3). The relative discriminating power was highest for PC1 (3.019) at $30.19 \%$, followed by PC 2 (2.37) at $23.67 \%$ and then PC $3(1.497)$ at $14.967 \%$; and these accounted for $68.814 \%$ of the total variability (Table 4 and Fig. 3).

Based on factor loading scores, PC1 had the highest importance for distinction since it could be differentiated by four parameters, i.e. external firmness (0.827), internal firmness (0.798), shelf life (0.714) and dry matter $(0.356 \%)$. The four properties were related to the morphological properties of the fruit and are, therefore, critical in defining pawpaw fruit properties, and hence determine selections for fruit quality. Fruit weight $(0.780 \mathrm{~kg})$ and pulp weight $(0.761 \mathrm{~kg})$ contributed to PCA 2. $\mathrm{pH}$ (0.526) and hard lump pulp (0.482 as a score) contributed to PCA 3; while total titratable acidity $(0.448 \%)$ and pulp thickness $(0.363$ $\mathrm{cm}$ ) contributed to the fourth and fifth components, respectively. Therefore, most of the observed variation within the accessions was due to the firmness of the fruit; followed by the weight of the fruit. Much as fruit firmness is highly heritable in pawpaw (LópezGómez et al., 2009), fruit weight is highly influenced by the environment ( Olubode $e t$ al., 2016). Thus, selection of contrasting genotypes in terms of firmness would allow 


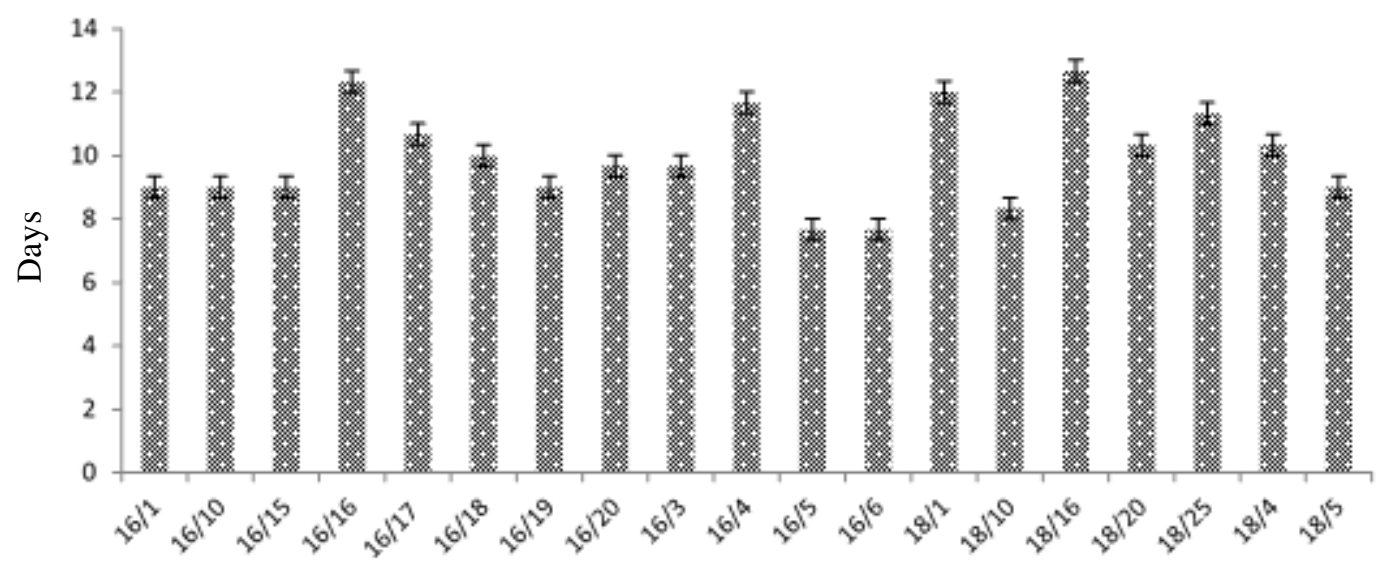

Accession code

Figure 1. Fruit shelf life (days) for accessions used in the study.

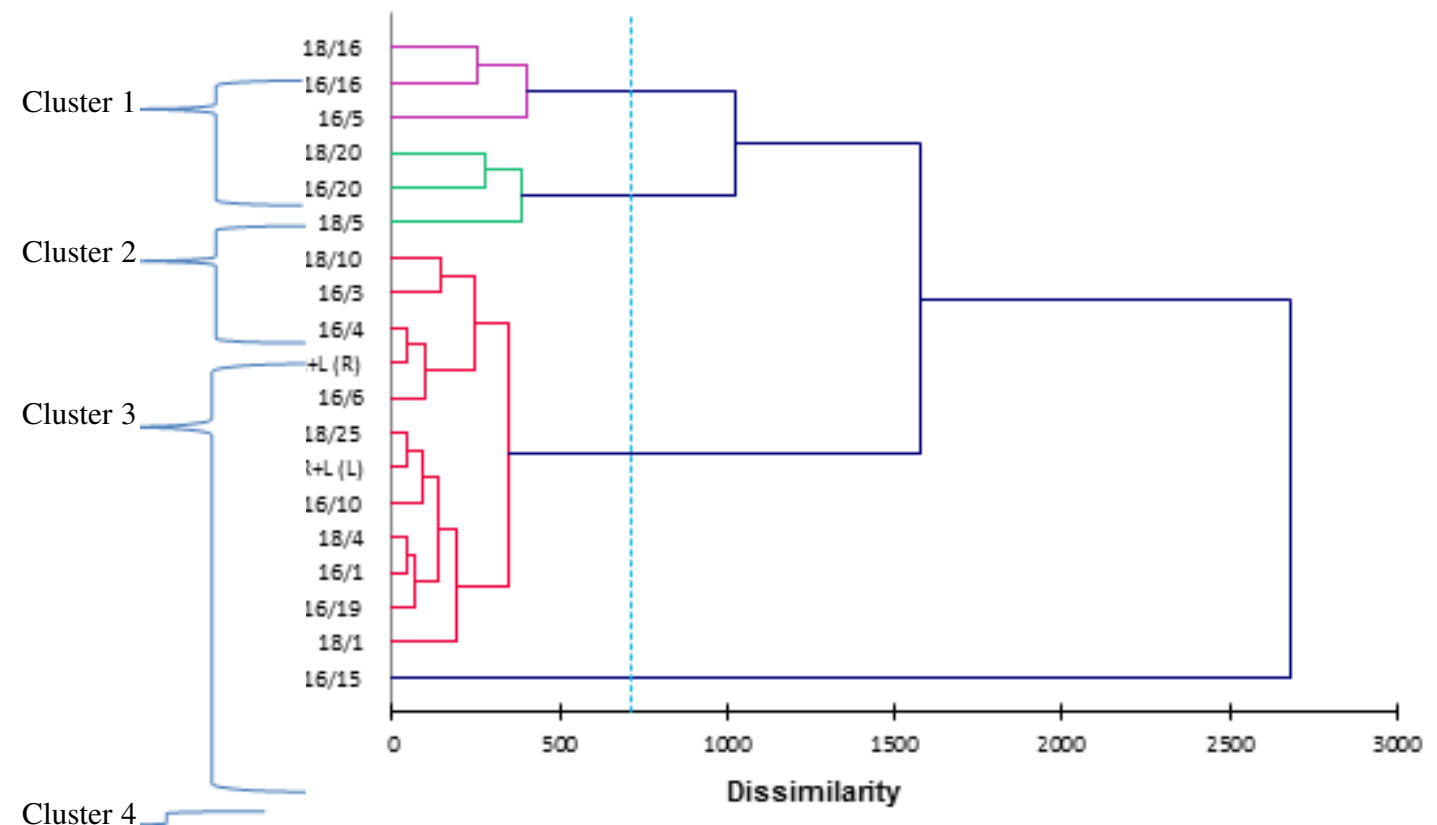

Figure 2. Dendrogram showing multivariate clustering of the 19 pawpaw germplasm by the 10 fruit quality parameters based on Euclidean distance using unweighted pair group mean average method.

for selection of good performing genotypes with the desired range of quality properties.

From the bi-plot (Fig. 4), a small angle of confluence was observed for external and internal firmness, shelf life and dry matter content of the fruit. Therefore, these four parameters were highly correlated to one another, and are the most important determinants of fruit shelf life. These parameters also defined the first PC, and are definitive of the morphological variations observed within the pawpaw fruits, as earlier observed by Olubode et al. (2016). Determination of any of these parameters, 


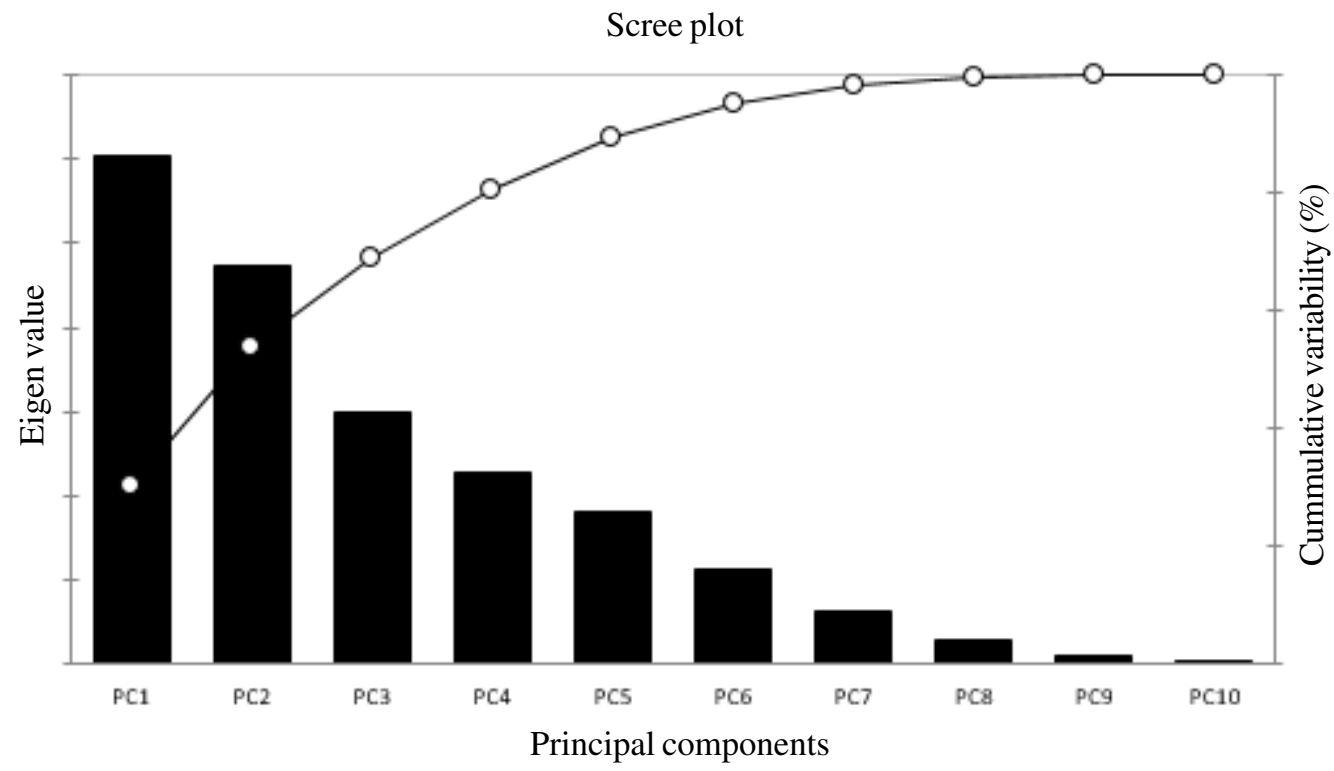

Figure 3. Relative contribution of each principal component in explaining variability. All the 10 components played a role in contributing to the variability within the pawpaw germplasm in terms of fruit quality.

Biplot (axes PC1 and PC2: $53.85 \%$ )

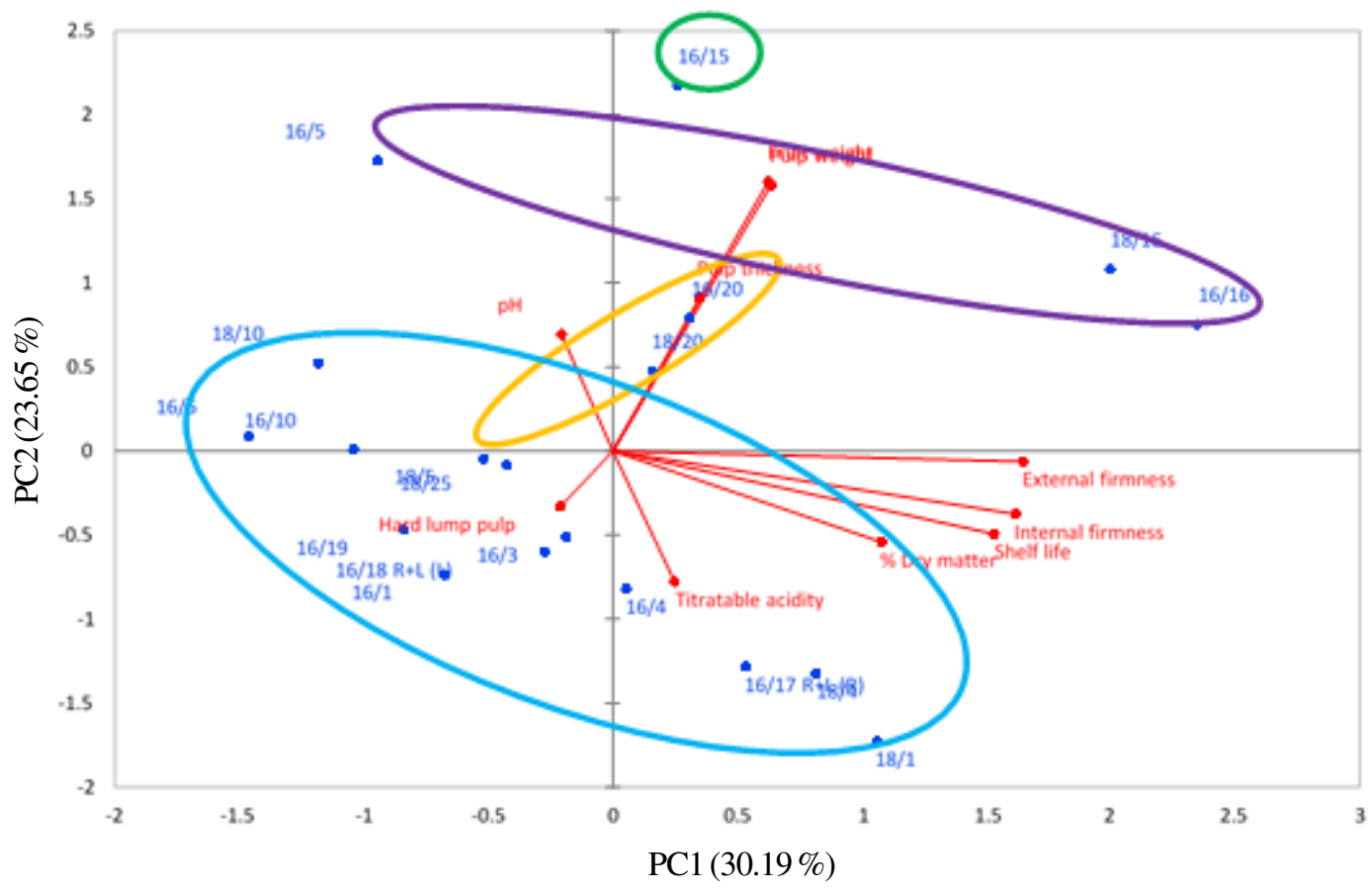

Figure 4. Biplot of the first two principal component factor scores and parameter loadings showing the four cluster groups of the 19 pawpaw germplasm. 
therefore, may be sufficient for drawing inferences about fruit shelf life, which is a crutial marketing parameter. Furthermore, these parameters can be easily measured, thus making breeding and selection for such traits possible within pawpaw germplasms. Hence, in phenotyping of pawpaw accessions during breeding, highly correlated parameters allow for the use of one of the easily measurable parameters for selection of the preferred genotypes.

Correlation analysis. To further define the observations in the bi-plot analysis of the parameters studied, a correlation analysis was undertaken and the results are shown in Table 5. Strong and highly significant $(\mathrm{P}<0.05)$ associations were realised between internal and external firmness $(r=0.879)$, showing that pulp firmness depends on the thickness of the skin and other inherent and heritable characteristics of the pulp. Firmness is an important parameter related to the shelf life of pawpaw fruits. Galli et al. (2007) observed that firmness is not improved by fruit physical treatment to increase shelf life. Therefore selection of varieties with desired firmness is paramount in the improvement of pawpaw quality.

Strong correlations were also observed between internal firmness and the fruit shelf life ( $r=0.74)$, showing that the firmer or harder the fruit, the more likely it will store for longer periods (Galli et al., 2007). Similar observations were seen between fruit shelf life and external firmness $(\mathrm{r}=0.81)$. Several factors influence fruit firmness in pawpaws; the most significant ones being pre harvest factors that are mainly related to the genetics of the pawpaw plant. These include the pawpaw fruit components of fiber, pigments, antioxidants and other secondary metabolites (Galli et al, 2009; Branan and Wang 2017). In addition, post-harvest factors in particular environmental factors such as intermittent warming during storage of pawpaw fruits have a significant effect on pawpaw fruit firmness (Galli, 2007). Thus, beyond selection of fruits with genetic factors that confer better fruit firmness properties, there is need to minimise the effect of environmental factors on the fruit. The strong positive correlation $(r=0.99)$ between pulp weight and fruit weight was observed. This is in relation to inherent fruit properties where the pulp makes almost $85 \%$ of the fruit and hence is the determinant of fruit weight and size (Galli et al., 2009; Olabode et al., 2016)

Total titratable acidity showed significant negative correlations with $\mathrm{pH}(-0.309)$. The negative relationship suggests poor buffer acid capacity of the pulp. Such observations are consistent with the report of Xu et al. (2012) on apples, where it was observed that increase in $\mathrm{pH}$ resulted into reduction in titratable acidity. Such components as earlier discussed were variable within the different fruits. The positive relationship between total titratable acidity and fruit DM (0.374) was indicative of the components of total titratable acidity of the fruit being part of the available solids in the fruit. Thus, the total determinants of titratable acidity in this case mainly included the organic acids and acidic salts present in the fruit pulp. This also indicates that by understanding these components, fruits with required total titratable acidity can be bred for in pawpaw fruit improvement programmes.

The observed relationships point to the availability of distinguishing features (morphological) that can be used in the selection of accessions with better performance in terms of fruit quality characteristics. They also point to the possibility of designing better utilisation strategies based on observable fruit traits such as firmness, which in turn influences the performance of the fruits after harvest. With pawpaw emerging as one of the speciality crops for both internal and export marketing (Cantaluppi, 2016), and given that fruit treatment procedures do affect the fruit ripening process and lower fruit quality (Galli et al., 2007; Galli et al., 2009), the selection 
of better performing accessions is of paramount importance. This study, therefore, provides a detail of the main quality determinants in pawpaw fruits and a basis for selection of better fruits based on correlated traits between the chemical and physical components of the fruit.

\section{CONCLUSION}

Understanding crop based variabilities is important in the improvement of crops both in terms of their genetics and utilisation. In this study, the characteristics of pawpaw fruits from Ugandan pawpaw germplasm were studied. Specific and accession based variabilities were observed which are relevant in the selection of pawpaw accessions for fruit quality and shelf life. Particularly, we observed that morphological based variability in fruit dry matter and weight based properties, in addition to pulp characteristics, are definitive in the determination of the shelf life of pawpaw fruits. This information is important in the design and implementation of pawpaw post-harvest improvement practices, such as storage technologies and transportation mechanisms for pawpaw fruits. The information is also important in formulating a local marketing strategy depending on the farmers' choice of accessions. The study also identified four main clusters of pawpaw in Uganda, germplasm with distinctive characteristics. This is important in designing a "variety" application strategy where each "variety" can be targeted for different uses or use segments. Accordingly, from correlation analysis, the study identified shelf life as one of the main contributors to fruit variability. Given the importance of shelf life in the marketability and hence acceptability of pawpaw fruits, it was observed that the main determinants for fruit shelf life included the external and internal fruit firmness and the dry matter content of the fruit. Thus determination of accession dry matter content is important in selecting fruits with higher shelf life. This study will also inform the use of pawpaw in other new applications that have not been in place, hence production of novel pawpaw products that will expand the application scale of pawpaw.

\section{ACKNOWLEDGEMENT}

This work was funded by the National Agricultural Research Organisation through the Government of Uganda development funds. We acknowledge the Horticultural programme at National Crops Resources Research Institute (NaCRRI) for availing the germplasm for evaluation; and the Makerere University, Department of Agricultural Production staff for guidance during the implementation of these activities.

\section{REFERENCES}

Addai, Z.R. Abdullah, A. Mutalib, S.A. Musa, K.H. and Douqan, E.M. 2013. Antioxidant activity and physicochemical properties of mature papaya fruit (Carica papaya L. cv. Eksotika). Advance Journal of Food Science and Technology 5(7):859-865

Archbold, D.D. and Pomper, K.W. 2003. Ripening pawpaw fruit exhibit respiratory and ethylene climacterics. Postharvest Biology and Technology 30(1):99-103.

Awe, S. Eniola, K.I.T. and Kayode-Ishola, T.M. 2013. Proximate and mineral composition of locally produced pawpaw and banana wine. American Journal of Research Communication 1(12):390-397.

Brannan, R.G. and Wang, G. 2017. Effect of frozen storage on polyphenol oxidase, antioxidant content, and color of pawpaw (Asimina triloba [L.] Dunal) fruit pulp. Journal of Food Research 6(3):93-101.

Bosquez-Molina, E. Ronquillo-de Jesús, E. Bautista-Baños, S. Verde-Calvo, J.R. and Morales-López, J. 2010. Inhibitory effect of essential oils against Colletotrichum gloeosporioides and Rhizopus stolonifer in stored papaya fruit and their possible 
application in coatings. Postharvest Biology and Technology 57(2):132-137.

Bosquez-Molina, E. Tomás, S.A. and Rodríguez-Huezo, M.E. 2011. Influence of $\mathrm{CaCl} 2$ on the water vapor permeability and the surface morphology of mesquite gum based edible films. LWT-Food Science and Technology 43(9):1419-1425.

Cantaluppi, C.J. 2016. The pawpaw: An emerging specialty crop. Journal of the NACAA 9(1).

Casals, J. Pascual, L. Canizares, J. CebollaCornejo, J. Casañas, F. and Nuez, F. 2012. Genetic basis of long shelf life and variability into Penjar tomato. Genetic Resources and Crop Evolution 59(2):219229.

Chutichudet, B. and Chutichudet, P. 2014. Effects of chitosan or calcium chloride on external postharvest qualities and shelf-life of 'Holland'Papaya fruit. Journal of Agricultural Science 6(11):160.

Crabtree, S.B. Pomper, K.W. and Lowe, J.D. 2010. Within-cluster hand-thinning increases fruit weight in North American pawpaw [Asimina triloba (L.) Dunal]. Journal of American Pomological Society 64(4):234.

Crisosto, C.H. Crisosto, G.M. and Metheney, P. 2003. Consumer acceptance of 'Brooks' and 'Bing' cherries is mainly dependent on fruit SSC and visual skin color. Postharvest Biology and Technology 28(1):159-167.

De Oliveira, J.G. and Vitória, A.P. 2011. Papaya: Nutritional and pharmacological characterization, and quality loss due to physiological disorders. An overview. Food Research International 44(5):1306-1313.

Galli, F. Archbold, D.D. and Pomper, K.W. 2009. Pawpaw fruit chilling injury and antioxidant protection. Journal of the American Society for Horticultural Science. 134(4):466-471.

Galli, F., Archbold, D.D. and Pomper, K.W. 2007. Heat treatment and intermittent warming fail to slow loss of firmness and mould development of pawpaw fruit
(Asimina triloba (L.) Dunal). In Novel approaches for the control of postharvest diseases and disorders. Proceedings of the International Congress 185-19.

Iroka, C.F. Akachukwu, E.E. Adimonyemma, R.N. Okereke, N.C. and Nwogiji, C.O. 2016. Effects of induced ripening on the proximate, biochemical and mineral compositions of Carica papaya (Pawpaw Fruit). European Journal of Medicinal Plants. pp. 1-10.

Koslanund, R. Archbold, D.D. and Pomper, K.W. 2005. Pawpaw [Asimina triloba (L.) Dunal] fruit ripening. II. Activity of selected cell-wall degrading enzymes. Journal of the American Society for Horticultural Science 130(4):643-648.

López-Gómez, R. Cabrera-Ponce, J.L. Saucedo-Arias, L.J. Carreto-Montoya, L. Villanueva-Arce, R. Díaz-Perez, J.C. Gómez-Lim, M.A. and Herrera-Estrella, L. 2009. Ripening in papaya fruit is altered by ACC oxidase cosuppression. Transgenic Research 18(1): 89-97.

Marpudi, S.L. Abirami, L.S.S. and Srividya, N. 2011. Enhancement of storage life and quality maintenance of papaya fruits using Aloe vera based antimicrobial coating. nopr.niscair.res.in

Nwofia, G.E. and Okwu, Q.U. 2012. Studies on nutritive characteristics and variability in pawpaw (Carica papaya L.). Pakistan Journal of Nutrition 11(10):859.

Olubode, O.O. Odeyemi, O.M. and Aiyelaagbe, I.O.O. 2016. Influence of environmental factors and production practices on the growth and productivity of pawpaw (Carica papaya L.) in south western Nigeria: A review. Fruit 71(6):341-361.

Osman, M.S. Sivakumar, D. and Korsten, L. 2011. Effect of biocontrol agent Bacillus amyloliquefaciens and 1-methyl cyclopropene on the control of postharvest diseases and maintenance of fruit quality. Crop Protection 30(2):173-178.

Othman, O.C. 2009. Physical and chemical composition of storage-ripened papaya 
(Carica papaya L.) fruits of Eastern Tanzania. Tanzania Journal of Science 35(1):47-56.

Paull, R.E. Nishijima, W., Reyes, M. and Cavaletto, C. 1997. Postharvest handling and losses during marketing of papaya (Carica papaya L.). Postharvest Biology and Technology 11(3):165-179.

Proulx, E., Cecilia, M., Nunes, N., Emond, J.P. and Brecht, J.K. 2005. Quality attributes limiting papaya postharvest life at chilling and non-chilling temperatures. Proceedings of the Florida State Horticultural Society 1 (118):389-395.

Shiga, T.M., Fabi, J.P., do Nascimento, J.R.O., Petkowicz, C.L.D.O., Vriesmann, L.C., Lajolo, F.M. and Cordenunsi, B.R. 2009. Changes in cell wall composition associated to the softening of ripening papaya: evidence of extensive solubilization of large molecular mass galactouronides. Journal of Agricultural and Food Chemistry 57(15):7064-7071.

Schweiggert, R.M. Steingass, C.B. Heller, A. Esquivel, P. and Carle, R. 2011. Characterization of chromoplasts and carotenoids of red-and yellow-fleshed papaya (Carica papaya L.). Planta 234(5): 1031.

Weekly Market Insights. 2018. https:// www.selinawamucii.com/insights/market/ uganda/pawpaws-papayas/

Xu, K. Wang, A. and Brown, S. 2012. Genetic characterization of the Ma locus with $\mathrm{pH}$ and titratable acidity in apple. Molecular Breeding 30(2):899-912. 